\title{
Adam Ferguson on the Perils of Popular Factions and Demagogues in a Roman Mirror
}

\author{
Max Skjönsberg, St Andrews
}

For the Scottish Enlightenment thinker Adam Ferguson (1723-1816) and many of his time, the history of the Roman Republic furnished the best case study for discussions of internal threats to a mixed system of government. These included factionalism, popular discontent, and the rise of demagogues seeking to concentrate power in their own hands. Ferguson has sometimes been interpreted as a 'Machiavellian' who celebrated the legacy of Rome and in particular the value of civic discord. By contrast, this article argues that he is better understood as a disciple of Montesquieu, who viewed Rome as an anachronistic and dangerous ideal in the eighteenth century, the era of the civilized and commercial monarchy. The greatest fear of Ferguson was military despotism, which was the likely outcome of democratic chaos produced by the levelling instincts of the 'common' people and demagogues prepared to harness their discontent. In such a scenario, a legitimate order in a mixed government would be turned into a faction putting the constitutional balance at risk, undermining intermediary powers, and ending liberty for all.

Like many political thinkers in the eighteenth century, Adam Ferguson (1723-1816) approached questions of empire, constitutionalism, and faction through the lens of the rise and fall of the Roman Republic. Ferguson's understudied History of the Progress and Termination of the Roman Republic (1783) has often been referred to as a straightforward narrative history, which is also how the author himself presented it. ${ }^{1}$ Yet within the narrative, we will see that Ferguson evaluated events from the standpoint of a moralist and political thinker. The story was a familiar one, but eighteenth-century authors emphasized different elements and drew different conclusions depending on their political opinions and commitments. Ferguson often left lessons implicit in his rendition of events, but on several occasions he clearly stated his views. Although a strong believer in presenting historical facts

${ }^{1}$ Adam Ferguson, 'Advertisement' (1805), The History of the Progress and Termination of the Roman Republic (1783), (5 vols., Edinburgh, 1825), 1:xxxvi-xxxvii. 
in a plain rather than ornamented way, for him the chief vale of this information was 'to become prudent in guarding against one event and in taking measures to obtain another.'2 This is especially relevant for his discussion of factionalism. Although he very rarely cited Machiavelli, it has often been said that Ferguson advanced a 'Machiavellian' argument in favour of civic discord. ${ }^{3}$ Importantly, however, Ferguson's history reveals much more about the kind of political division he strongly disapproved of: popular, or democratic, factions with the potential of creating chaos and giving rise to military despotism.

Ferguson's Roman Republic is far from being as celebrated as Edward Gibbon's History of the Decline and Fall of the Roman Empire (1776-89), and it was initially somewhat of a commercial failure before going through numerous editions in the first half of the nineteenth century. ${ }^{4}$ It had been completed when the author had been seriously ill, and according to the autobiography of his friend Alexander Carlyle, Ferguson 'had not been able to correct it diligently. ${ }^{, 5}$ Despite this, Adam Smith, one of the proof-readers of the manuscript, allegedly thought it had 'the highest degree of merit', and it was one of the young J. S. Mill's favourite books. ${ }^{6}$ Carlyle ascribed the degree of disparagement the book met with on his initial publication to jealousy, adding that 'there were a few of us who could not refrain from saying that Ferguson's was the best history of Rome.' ${ }^{7}$ Even though the Roman

\footnotetext{
${ }^{2}$ Ferguson, 'Of History and its Appropriate Style' (1806), The Manuscripts of Adam Ferguson, ed. Vincenzo Merolle (London, 2006), 21.

${ }^{3}$ This argument is commonly called 'Machiavellian', although Machiavelli himself differentiated between beneficial and harmful divisions in Istorie Fiorentine (1525) and elsewhere. Pocock refers to Ferguson as the most 'Machiavellian' of the Scottish thinkers, and later labelled him 'the Moderate as Machiavellian'; see The Machiavellian Moment (1975), (Princeton, 2003), 499; idem, Barbarism and Religion (6 vols., Cambridge, 1999-2015), 2:330. For Ferguson as a supporter of civic discord, see Andreas Kalyvas and Ira Katznelson, Liberal Beginnings: Making a Republic for the Moderns (New York, 2008), 51-87; Lisa Hill, The Passionate Society: The Social, Political and Moral Thought of Adam Ferguson (Dordrecht: Springer, 2006), 8, 17, 123-38, 234; idem, 'Eighteenth-Century Anticipations of the Sociology of Conflict: The Case of Adam Ferguson', Journal of the History of Ideas, 62 (2001), 281-99; Silvia Sebastiani, 'Beyond Ancient Virtues: Civil Society and Passions in the Scottish Enlightenment', History of Political Thought 32 (2011), 837-8; Fania OzSalzberger, Translating the Enlightenment: Scottish Civic Discourse in Eighteenth-Century Germany (Oxford, 1995), 114-16; David Kettler, 'History and Theory in Ferguson's Essay on the History of Civil Society: A Reconsideration', Political Theory (5) 1977, 452-3.

${ }^{4}$ Richard Sher, The Enlightenment and the Book: Scottish Authors \& Their Publishers in EighteenthCentury Britain, Ireland, \& America (Chicago and London, 2006), 252-3. The popularity of the Roman Republic in the early nineteenth century calls into question David Kettler's sweeping statement that Ferguson's 'reputation suffered an abrupt eclipse at the beginning of the nineteenth century'; see Kettler, The Social and Political Thought of Adam Ferguson (Columbus, 1965), 3-4.

${ }^{5}$ Autobiography of the Reverend Dr Alexander Carlyle, Minister of Inveresk, containing Memorials of the Men and Events of his Time (2 ${ }^{\text {nd }}$ ed., Edinburgh and London, 1860), p. 284.

${ }^{6}$ Carlyle to John Douglass, 14 March 1781, British Library, Egerton MS 2185, f. 103; Mill, Autobiography (London, 1924), 10-11. We should note, however, that Smith's praise may have been part of a concerted effort to ensure Ferguson a remuneration of $£ 2,000$ for its copyright; see Sher, The Enlightenment and the Book, 252.

${ }^{7}$ Carlyle also wrote that 'David Hume did not live to see Ferguson's History, otherwise his candid praise would have prevented all the subtle remarks of the jealous and resentful.' See Carlyle, Autobiography, p.
} 
Republic appears to have kept Ferguson's name alive in the nineteenth century, his reputation today rests mainly on his Essay on the History of Civil Society (1767). In contrast with the Essay, the Roman Republic has not received much attention from intellectual historians, with the important exceptions of J. G. A. Pocock and Iain McDaniel. ${ }^{8}$ Fergus Millar, for example, consciously excludes Ferguson to focus on Montesquieu and Rousseau, since they (by implication unlike him) put the Roman past to 'constructive use. ${ }^{\text {9 }}$ While perhaps understandable, this neglect is regrettable since Millar complains that commentators from James Madison to Samuel Finer have routinely ignored the late republic in favour of the early history of Rome. ${ }^{10}$ As we shall see, Ferguson would have provided a counter-example.

By focusing on factionalism and the related question of demagoguery in the Roman Republic, this article will show that Ferguson's views on the subject of civic discord were much more negative and even alarmist than has often been claimed. His contribution reflects a concern with political stability fitting neatly into eighteenth-century Scottish culture, which was divided into Jacobites and Whigs, Highland and Lowland, ${ }^{11}$ Episcopalians and Presbyterians, and the Popular Party and Moderates within the Kirk. ${ }^{12}$ One of Ferguson's preferred remedies was the establishment of a citizen militia, for which the Roman Republic was of the greatest interest. ${ }^{13}$ While this part of his project has been thoroughly examined, especially by McDaniel, this article will look closely at another central but less appreciated aspect of Ferguson's thought: his adherence to a strict and rather 'elitist' interpretation of

285. This is not unthinkable since Hume and Ferguson were very close and longstanding friends, despite intellectual disagreements (see note 20).

${ }^{8}$ Iain McDaniel, Adam Ferguson in the Scottish Enlightenment: The Roman Past and Europe's Future (Cambridge MA, 2013), 119-154; idem, 'Ferguson, Roman History and Threat of Military Government in Modern Europe', in Adam Ferguson: History, Progress and Human Nature, ed. Eugene Heath and Vincenzo Merolle (London and New York, 2008), 115-130. For Pocock, see note 3.

${ }^{9}$ Fergus Millar, The Roman Republic in Political Thought (Hanover and London, 2002), 108.

${ }^{10}$ Ibid, 131, 151.

${ }^{11}$ As a Gaelic speaker born on the border between the Highlands and the Lowlands, the importance of Ferguson's background for his intellectual interest in primitive societies has often been overemphasised. This was an interest he shared with most Scottish Enlightenment thinkers endeavouring to understand human sociability and societal change. On this, see John D. Brewer, 'Putting Adam Ferguson in His Place', The British Journal of Sociology, 58, 1 (2007), 105-22.

12 The best introduction is David Allan, Scotland in the Eighteenth Century: Union and Enlightenment (London and New York: Routledge, 2002). Christopher Berry has coined the term 'institutional stickiness' to explain the importance of stability for the eighteenth-century Scots; see Essays on Hume, Smith and the Scottish Enlightenment (Edinburgh, 2018), 75-87. See also Roger Emerson, Essays on David Hume, Medical Men and the Scottish Enlightenment: 'Industry, Knowledge and Humanity' (Farnham, 2009), 239-42.

${ }^{13}$ Ferguson, Reflections Previous to the Establishment of a Militia (London, 1756); idem, 'Of Statesmen and Warriours' (1799-1803) and 'Of the Separation of Departments[,] Professions and Tasks Resulting from the Progress of Arts in Society' (1806), The Manuscripts of Adam Ferguson, 33-46, 143-52. See also McDaniel, Adam Ferguson, 155-82. 
mixed constitutionalism. ${ }^{14}$ An anonymous friend cited in Ferguson's obituary appropriately described him as 'a constitutional Whig, equally removed from Republican licentiousness, and Tory bigotry. ${ }^{, 15}$

Looking at Ferguson's Roman Republic has the benefit of complementing and to some degree problematizing the thesis of Benjamin Straumann in what is certainly the most significant work on the legacy of Roman political thought in intellectual history in recent years. ${ }^{16}$ Straumann correctly identifies constitutionalism as the most important intellectual inheritance of Rome, an argument intended to undermine Benjamin Constant's famous distinction between ancient and modern liberty. ${ }^{17}$ In the process, Straumann points to a sharp dichotomy between political thinkers emphasizing constitutional safeguards, such as Polybius, Cicero, Bodin, Montesquieu, Hume, John Adams, among others, and those extolling the importance of civic virtue, including Livy, Machiavelli, Rousseau and many of the French revolutionaries. ${ }^{18}$ This is meant to qualify the disproportionate stress placed on virtue in Pocock's and Quentin Skinner's highly influential work on the history of republicanism. ${ }^{19}$ It is unclear, however, on which side of this divide Ferguson, who is only mentioned three times in Straumann's book, could be placed. As we shall see, Ferguson remained attentive to both constitutionalism and the importance of virtue for the simple reason that self-seeking individuals and corrupted peoples are less inclined to respect constitutional rules. Constitutional safeguards can protect rights in the ordinary run of things, but they are unlikely to survive periods of extreme factionalism. For Ferguson it was not a question of either/or; these two aspects of politics were intimately connected, and they were both crucial. In this context, Ferguson's line can be seen as a rejection of his friend David Hume's essay 'That Politics May be Reduced to a Science' (1741), which had argued that the benefit of free governments was that they, unlike absolute monarchies, did not have to rely on

${ }^{14}$ Ferguson, Essay on the History of Civil Society (1767), (Cambridge, 2007), 157-61, 252.

${ }^{15}$ The Annual Biography and Obituary, for the Year 1817 (London, 1817), 236. For a consideration of Ferguson's place in the traditions of conservatism and liberalism, respectively, see Craig Smith, 'Adam Ferguson and the Danger of Books', Journal of Scottish Philosophy, 4 (2006), 93-109; Kalyvas and Katznelson, Liberal Beginnings, 51-87. We should note, however, that conservatism and liberalism are both nineteenthcentury labels and there were no such philosophies, movements or parties in the eighteenth century.

${ }^{16}$ Benjamin Straumann, Crisis and Constitutionalism: Roman Political Thought from the Fall of the Republic to the Age of Revolution (New York, 2016).

${ }^{17}$ Ibid, 5-21. Interestingly, Straumann traces this distinction to Ferguson in one of his few references to him.

${ }^{18}$ Ibid, 262, 303-41.

${ }^{19}$ Pocock, The Machiavellian Moment; Quentin Skinner, Liberty before Liberalism (Cambridge, 1998). 
the qualities of particular individuals since their 'checks and controuls' were sufficient to make it in the interest 'even for bad men, to act in the public good.'20

The first section discusses Ferguson's intentions and reasons for writing the Roman Republic, and places it in the context of the debate about internal division in British eighteenth-century political thought. In the second section, this article offers a brief sketch of the ways in which division in Rome has been treated by historians and thinkers from Livy to Montesquieu. In the third section, we turn to Ferguson's history itself to see how he built on and differed from earlier narratives, including the ones already mentioned but also British contributors such as Walter Moyle and Nathaniel Hooke. In the fourth section, this article discusses Ferguson's view of modern politics with particular emphasis on his views on political representation in Britain in contrast with ancient Rome. By way of conclusion, this article offers some suggestions about what the Roman Republic can tell us about Ferguson as a political thinker, and how it fits within eighteenth-century thought about political disintegration, with particular emphasis on his Scottish milieu but also in a larger perspective. I also seek to relate the political messages of the Roman Republic with Ferguson's earlier and more famous Essay.

\section{I: THE LEAD-UP TO ROME}

This article situates Ferguson in a European conversation about internecine discord, one which was particularly relevant for the British parliamentary system of government. Ferguson was a Scottish Enlightenment thinker and although he rarely mentioned Scotland and even admitted to be uninterested in Scottish history, his agenda and interests were heavily informed by the intellectual environment of his native land. ${ }^{21} \mathrm{He}$ was, however, also part of the generation of Scottish 'Whig' historians who, in the words of Colin Kidd, 'adopted an Anglo-British institutional identity'. ${ }^{22}$ Scotland had its own ancient constitutional tradition, but when Ferguson, born sixteen years after the parliamentary union with England of 1707, wrote of 'our constitution' to his friend and fellow Scotsman William (Johnstone) Pulteney

\footnotetext{
${ }^{20}$ Hume, Essays: Moral, Political, and Literary (Indianapolis, 1987), 15-16. The emphasis Ferguson placed on virtue in the Essay may explain Hume's dislike of it. However, Hume, who was one of Ferguson's closest friends, was pleasantly surprised when it turned out to be a critical success. See The Letters of David Hume, ed. J. Y. T. Greig (Oxford, 1932), 2:11-12, 120-1, 125-6, 133, 136.

${ }^{21}$ David Allan, 'Ferguson and Scottish History: Past and Present in An Essay on the History of Civil Society', in Adam Ferguson: History, Progress and Human Nature, 23-38.

${ }^{22}$ Colin Kidd, Subverting Scotland's Past: Scottish Whig Historians and the Creation of an AngloBritish Identity, 1689-1830 (Cambridge, 1993), 99.
} 
MP in $1769,{ }^{23}$ he meant a somewhat idealized version of the constitution of 'Great Britain' what foreigners such as Montesquieu and Delolme referred to as the English constitution. His thought about party conflict can fruitfully be placed in an Anglo-British context, of which parliamentary parties had been a part since the Exclusion Crisis of 1678-81. ${ }^{24}$

'Party' and 'faction' were frequently treated synonymously in British political debate in the eighteenth century. ${ }^{25}$ Both could either mean parliamentary constellation (Whig and Tory; Court and Country) or carry the more sinister connotation of civil war-like division with its roots in the Reformation and the civil wars of the seventeenth century (Cavalier and Roundhead; Episcopalian and Puritan; republican and Jacobite). Party was traditionally seen as a force of constitutional disintegration, classically described as such in Joseph Addison's Spectator essays no. 125 and $126 .{ }^{26}$ An alternative take on party was offered by Bernard Mandeville who argued in the second part of the Fable of the Bees (1729) that 'Quarrels between Parties, are a considerable Part of the Nation's Security. ${ }^{27}$ Mandeville's argument was predicated on an egoistic moral psychology which generated considerable debate in Scotland. Francis Hutcheson sought to refute Mandeville, as he put emphasis on disinterested virtue and love of benevolence. ${ }^{28}$ If Hume and Smith accepted, even as they heavily qualified, aspects of Mandeville's depreciation of disinterested virtue and benevolence as essential to public life, ${ }^{29}$ then Ferguson occupied a position closer to Hutcheson's, in stressing that constitutional mechanisms alone could not make up for the absence of benevolence, public spiritedness and patriotism. Accordingly, notions such as ambition and

${ }^{23}$ Ferguson to William Pulteney, 7 Nov 1769, The Correspondence of Adam Ferguson (2 vols., London, 1995), 1:80. See also 1:226, 2:292.

${ }^{24}$ Robert Willman, "The Origins of "Whig" and "Tory" in English Political Language', Historical Journal, 17 (1974), 247-264.

${ }^{25}$ Nancy L. Rosenblum, On the Side of the Angels: An Appreciation of Parties and Partisanship (Princeton, 2008); Terence Ball, 'Party', Political Innovation and Conceptual Change, ed. Ball et al., (Cambridge, 1989); Harvey C. Mansfield Jr., Statesmanship and Party Government: A Study of Burke and Bolingbroke (Chicago, 1965); Caroline Robbins, "Discordant Parties": A Study of the Acceptance of Party by Englishmen', Political Science Quarterly, 73 (1958), 505-29.

${ }^{26}$ Henry G. Bohn (ed.), The Works of Joseph Addison (6 vols., London, 1888-1902), 2:475-81.

${ }^{27}$ Bernard Mandeville, The Fable of the Bees or Private Vices, Publick Benefits $(1714,1729)$, ed. F.B. Kaye (2 vols., Oxford, 1924), 2:334.

${ }^{28}$ Francis Hutcheson, Inquiry into the Original of our Ideas of Beauty and Virtue (2nd ed., 1726), (Indianapolis, 2008), 103.

${ }^{29}$ John Robertson, The Case for the Enlightenment (Cambridge, 2005), 256-324; Mikko Tolonen, Mandeville and Hume (Oxford, 2013). Some of the literature on the relationship between Mandeville, Hume and Smith underestimates the extent to which the latter two sought to rebut some of the more extreme claims of the former, and they certainly wanted to distance themselves from Mandeville's reputation. See Hume, Treatise on Human Nature (1739-40), (Oxford, 1978), 486-7; idem, 'Of the Dignity and Meanness of Human Nature' (1741), Essays, 80-6; Smith, The Theory of Moral Sentiments (1759), (Indianapolis, 1984), 9-16, passim. 
partisanship were double-edged for Ferguson, and their merits or demerits rested on whether they were motivated by selfless benevolence and patriotism, or lust for private gain.

Ferguson had dealt extensively with partisanship and division prior to his Roman history. In the Essay, he argued that human beings have a natural propensity for friendship as well as antagonism, union as well as discord, and suggested that the two sentiments are mutually reinforcing. ${ }^{30}$ In the same work, he sketched how opposition between 'parties', in the sense of different parts of the constitution, could be beneficial in a mixed system of government, as it often generated moderate laws as a result of compromise between different orders in the state. ${ }^{31}$ These views have led many commentators to describe Ferguson as an advocate of political conflict and a supporter of faction. ${ }^{32}$ We learn from Ferguson's correspondence, however, that he is unlikely to have approved of such descriptions. ${ }^{33}$ For example, in a series of letters to his friend the Scottish parliamentarian William (Johnstone) Pulteney, he expressed his dissatisfaction with the new form of opposition party that emerged in the late 1760s in the shape of the Rockingham Whigs - the party defended by their loyal member and publicist Edmund Burke in his Thoughts on the Cause of the Present Discontents (1770). ${ }^{34}$ Ferguson was deeply disturbed by the Rockingham Whigs' perceived willingness to exploit popular discontent, particularly over the question of 'Wilkes and liberty.' 35

Upon receiving a government pension, Ferguson wrote a pamphlet in 1776 in support of the Lord North administration's policy on America - a response to Richard Price's influential Observations on the Nature of Civil Liberty (1776). ${ }^{36}$ The pamphlet shows that Ferguson agreed fully with Montesquieu in his interpretation of civil liberty as security under the rule of law. ${ }^{37}$ In contrast with Price's plea for self-government, Ferguson stressed that 'the

\footnotetext{
${ }^{30}$ Ferguson, Essay, 21-9. For Ferguson's theory of sociability, see McDaniel, Adam Ferguson in the Scottish Enlightenment, 64-91.

${ }^{31}$ Ferguson, Essay, 124-5.

32 See note 3.

${ }^{33}$ Max Skjönsberg, 'Adam Ferguson on Partisanship, Party Conflict, and Popular Participation', Modern Intellectual History (Online First 2017).

${ }^{34}$ Richard Bourke, Empire and Revolution: The Political Life of Edmund Burke (Princeton, 2015), 192201, 257-66.

${ }^{35}$ Ferguson to William Pulteney, 7 November 1769, Correspondence, 1:83.

${ }^{36}$ Ronald Homowy, 'Scottish Thought and the American Revolution: Adam Ferguson's Response to Richard Price', Liberty and American Experience in the Eighteenth Century, ed. David Womersley (Indianapolis, 2006).

${ }^{37}$ For Montesquieu's influential interpretation of liberty, see Annelien de Dijn, 'On political liberty: Montesquieu's missing manuscript', Political Theory 39 (2011), 181-204. It is evident that Ferguson understood liberty in similar terms; see [Ferguson], Remarks on a Pamphlet lately Published by Dr. Price, intitled Observations on the Nature of Civil Liberty (London, 1776), 14; idem, Institutes, 288-9; idem, Principles of
} 
power of the people is not the good of the people', ${ }^{38}$ pointing to the history of the Roman Republic as the prime example of how liberty 'perished at last by the very hands that were employed in support of the popular cause. ${ }^{39}$ In the pamphlet he wrongly predicted that it was only a matter of time before an American officer would rise up and emasculate Congress as a Caesar or a Cromwell. Some expected George Washington to play such a role, but he 'stunned the world' when he resigned as general after the American victory in $1783 .{ }^{40}$

We can surmise that the popular discontent and party struggle of the $1760 \mathrm{~s}$ and $1770 \mathrm{~s}$ - and especially the Wilkes episode with all the examples it furnished of popular tumult and the willingness of ambitious party politicians to exploit such discontent - played a role in guiding Ferguson towards his next major project after the Essay and the Institutes of Moral Philosophy (1769) ${ }^{41}$ In the spring of 1776, he wrote the following to Gibbon: 'I have as you suppose been employed at any intervals of Leisure or rest I have had for some years, in taking notes or collecting Materials for a History of the Disstractions that broke down the Roman Republic \& ended in the Establishments in Augustus \& his immediate Successors', adding that 'I comfort myself that as my trade is the Study of human Nature I coud not fix on a more interesting Corner of it than the end of the Roman Republic. ${ }^{42}$

Unlike Gibbon, who wrote about the Roman Empire in the Christian era and its fall in West and East, explained partly as a result of Christianity, Ferguson turned to the pagan Republic. Part of the explanation may have been that he needed to do something different from Gibbon, who had begun publishing in 1776. Yet it is clear from Ferguson's earlier writings and correspondence, especially the letter to Gibbon cited above, that it was the era of the late Republic, when the Senate was powerful, which interested Ferguson the most. The history of Christianity appears to have been of limited interest to Ferguson, and paradoxically the reason may have been his faith rather than lack thereof as in the probable case of Gibbon

Moral and Political Science (2 vols., Edinburgh, 1792), 2:459. For Montesquieu's impact on Ferguson, see Sheila Mason, 'Ferguson and Montesquieu: Tacit Reproaches', British Journal for Eighteenth-Century Studies 11/2 (1988), 193-204; Richard Sher, 'From Troglodytes to Americas: Montesquieu and the Scottish Enlightenment on Liberty, Virtue, and Commerce', in Republicanism, Liberty, and Commercial Society, 1649. 1776, ed. David Wootton (Stanford, 1994), 368-402; Alexander Broadie. Agreeable Connexions: Scottish Enlightenment Links with France (Edinburgh, 2012), ch. 6.

38 This was a paraphrase of Montesquieu, The Spirit of the Laws (1748), ed. Anne M. Cohler et al. (Cambridge, 2015), 155.

39 [Ferguson], Remarks, 52.

${ }^{40}$ Gordon Wood, The Radicalism of the American Revolution (New York, 1991), 205.

${ }^{41}$ In 1782, he wrote to his publisher William Strahan that 'I have been about twelve years employed on this Subject' (Correspondence, 2:284).

${ }^{42}$ Ferguson to Gibbon, 18 April 1776, Correspondence, 1:141. 
(and Hume). ${ }^{43}$ Ferguson, whose father was a parish minister, was himself ordained in the Scottish Presbyterian Church, and served as deputy and subsequently principal chaplain of the 'Black Watch', a Highland regiment in the British Army, between 1745 and 1754. After having left the army, and unsuccessfully applied for the living at a parish near Perth, he asked his friend Adam Smith to address him 'without any clerical titles, for I am a downright layman. ${ }^{44}$ This statement should certainly not be interpreted as any rejection or disillusion with the Church of Scotland since Ferguson served as an active Elder in the General Assembly of the Kirk for decades. ${ }^{45}$

Most of Ferguson's writings on the subject are about natural, rather than revealed, religion. Since he viewed the conflict between Presbyterianism and Episcopacy as settled in Scotland, his obituarist wrote that he 'always deemed the disputatious zeal of the preceding century, wholly inapplicable to the present; and speculative questions, tending to embitter the minds of men against each other, as unworthy of attention. ${ }^{46}$ The Essay lacks any extensive discussion of religion, although there are references to divine design, providence, the salutary effects of 'true religion', 'priesthood' as a political order, and 'the mild Spirit of Christianity ${ }^{47}$ His treatment of the subject in his published university lectures betrays a Scottish Enlightenment preoccupation with explaining the emergence and existence of different forms of religious worship. ${ }^{48}$ Unlike Hume, however, Ferguson never questioned either design or the existence of the afterlife. ${ }^{49}$ Ferguson was a broad-minded Christian who denounced 'False notions of religion, which interpose the authority of God in behalf of any frivolous or cruel practice'. ${ }^{50}$ Many of his unpublished essays written late in life are about religion in a broad sense, and his references are to ancient Stoic ideas about the cosmos rather than Scripture. In his letters to Gibbon he does not seem to have been much disturbed by the Englishman's take on Christianity: 'you have made a great addition to the Classical Literature

\footnotetext{
${ }^{43}$ On this, see Jeng-Guo S. Chen, 'Providence and Progress: The Religious Dimension in Ferguson's Discussion of Civil Society’, in Adam Ferguson: History, Progress and Human Nature, 171-86.

${ }^{44}$ Ferguson to Smith, October 1754, Correspondence, 1:10.

${ }^{45}$ Richard Sher, Church and University in the Scottish Enlightenment (1985), (Edinburgh, 2015), 12047.

46 The Annual Biography and Obituary, for the Year 1817, 236.

${ }^{47}$ Ferguson, Essay, 12, 89-90, 103, 192. He was criticised for ignoring religion in reviews by William Rose and others; see David Raynor, 'Why Did David Hume Dislike Adam Ferguson's Essay', in Adam Ferguson: Philosophy, Politics and Society, ed. Eugene Heath and Vincenzo Merolle (London and New York, 2009), 48-50.

${ }^{48}$ Ferguson, Principles, 1:163-71.

${ }^{49}$ Hume, Dialogues Concerning Natural Religion; idem, 'Of the Immortality of the Soul', in Essays, $590-8$

${ }^{50}$ Ferguson, Principles, 2:100.
} 
of England, and given us, what Thucydides purposed leaving with his own Countreymen, $\underline{A}$ Possession in Perpetuity...Some of your readers I find were impatient to get at the fifteenth Chapter [which together with the concluding sixteenth chapter deal with the growth of Christianity $^{51}$ ], and began at that place. I have not heard much of their Criticism but am told that many doubt of your Orthodoxy. I wish to be always of the Charitable side while I own you have proved that the Clearest stream may become foul when it comes to run over the muddy bottom of Human Nature. ${ }^{52}$ It was Ferguson's somewhat gloomy view of human nature, with its proneness to corruption and factionalism, which drew him to the Roman Republic, and particularly its late stage.

\section{II: FACTIONALISM AND TUMULT IN THE ROMAN REPUBLIC}

Living in the historical age of the historical nation ${ }^{53}$ and personally acquainted with the socalled triumvirate of British historians, ${ }^{54}$ it should not surprise us that Ferguson turned to history. Among friends and fellow Scots, Hume and William Robertson had achieved fame and fortune by writing the histories of England (1754-62) and Scotland (1759) respectively. Ferguson's History of the Progress and Termination of the Roman Republic, dedicated to George III, was initially published in three quarto volumes in 1783 and then in five very slightly revised but mainly corrected octavo volumes in 1799. From a British perspective, his choice of subject matter was not strange. Ferguson was born in the so-called Augustan age when many of his favourite authors were absorbed by Roman history, literature and culture. As the work of Pocock on Gibbon has illustrated, the overriding theme in the grand narratives of the period usually labelled 'Enlightenment' was the transformation of republic into empire, and the story about the incompatibility of liberty and empire. The paradigm case for this was Rome, and Ferguson's was the last such history of note in the eighteenth century, appearing after a surge of histories and essays on this period. ${ }^{55}$

The history of the Roman Republic was replete with tumult and disorder. The patrician and plebeian 'parties' - and later the parties of the nobles and the commons - were

\footnotetext{
${ }^{51}$ Pocock, Barbarism and Religion, 5: ch. 8-10.

52 Ferguson to Gibbon, 19 March 1776, Correspondence, 1:135-6.

${ }^{53}$ Described as such by Hume in The Letters of David Hume, 2:230-1.

${ }^{54}$ The triumvirate includes Hume, William Robertson, and Gibbon; see Gibbon, Memoirs of My Own Life (London: Penguin, 1990), 160.

${ }^{55}$ Frank M. Turner, 'British Politics and the Demise of the Roman Republic, 1700-1939', Historical Journal 29 (1986), 577-87.
} 
of course different from the British eighteenth-century parties, with the latter being intraparliamentary parties rather than social forces, and cut from the same aristocratic cloth instead of representing different orders in the state. For this reason, J. A. W. Gunn has argued that the comparison is misleading. ${ }^{56}$ Similarly, in her seminal work on the late republic, Valentina Arena stresses that the two main ideological families she identifies in the period (popularis and optimates) were not akin to modern political parties. ${ }^{57} \mathrm{Be}$ that as it may, many eighteenth-century writers approached internal conflict between political parties from the prism of factional strife in the Roman Republic, and the list of commentators contributing to this tradition includes Jonathan Swift and Thomas Gordon. ${ }^{58}$ Moreover, we do not have to agree with Gunn that the comparison was entirely pointless. Nancy Rosenblum has defended the comparison between the aristocratic political parties of the eighteenth century with later mass electoral parties on the basis that '[r]egulated rivalry, governing, and fruitful conflict have independent merit. ${ }^{59}$ We should also note that eighteenth-century parties were less organized than modern ones, and were often understood as large ideological 'families' in the sense of a system of thought which informed political behaviour.

The terms 'party' and 'faction' are derived from Latin. Although we do not know exactly how the distinction between patricians and plebs arose, the struggle between these two orders is central in accounts of Rome in the firth and fourth centuries BC in particular. ${ }^{60}$ The perhaps best-known ancient account of factional strife in the early Roman Republic is found in book two of Livy's History of Rome. Livy spoke of a division of fathers (patres), ${ }^{61}$ or senators, and plebs in $494 \mathrm{BC}$, springing from disagreement about the burden of debt held by the plebeians, which led to their secession and, eventually, the creation of the tribunes of the plebs. ${ }^{62}$ Livy condemned 'factionalism' along with private interestedness as things always hurtful to the public. ${ }^{63}$ The Roman historian also spoke of 'intestine discord' (discordiae intestinae), which would come to be one of the key phrases in later debates about party

\footnotetext{
${ }^{56}$ J. A. W. Gunn (ed.), Factions No More: Attitudes to Party in Government and Opposition in Eighteenth-Century England (London: Frank Crass, 1972), 14, 262-3.

${ }^{57}$ Valentina Arena, Libertas and the Practice of Politics in the Late Roman Republic (Cambridge, 2012), 8 .

${ }^{58}$ Ball, 'Party', 161.

${ }^{59}$ Rosenblum, On the Side of the Angels, 13.

${ }^{60}$ Millar, The Roman Republic in Political Thought, 17.

${ }^{61}$ Usually translated as 'patricians.'

${ }^{62}$ Livy, History of Rome: Volume I (Cambridge, 1989), bk. 2, ch. 23-33.

${ }^{63}$ Ibid, 30.2.
} 
strife. ${ }^{64}$ According to Livy, such discord in the city equalled disagreement among various body parts, which would lead to starvation. ${ }^{65}$

In his Discourses on Livy, Machiavelli had notoriously contended that tumult and discord between different orders of the state had been a blessing rather than a curse for the Romans, referring to the earlier history of Roman division. ${ }^{66}$ All republics have an upper and a lower class, according to Machiavelli, and those who condemn the quarrels between the grandi and the popolo, or nobili and plebe 'seem to be cavalling at the very things that were the primary cause of Rome's retaining her freedom. ${ }^{67}$ Machiavelli believed that 'every city should provide ways and means whereby the ambitions of the populace may find an outlet. ${ }^{96}$ More specifically, these 'tumults' had led to laws and institutions from which the public benefited, namely the tribunes of the plebs. The office of the tribunes made Rome a mixed government and a perfect commonwealth. ${ }^{69}$ Tumult accordingly deserved the highest praise, the Florentine concluded. ${ }^{70}$

As has been made familiar by Pocock, the Machiavellian idiom was transmitted into English political discourse in the mid-seventeenth century and became a lynchpin of what has become known as the commonwealth tradition. ${ }^{71}$ James Harrington and Algernon Sidney seem to have disagreed over the question of 'tumult' in the Roman Republic, with the former preferring internal tranquillity and the latter arguing that this sedition was generally 'harmless, or profitable. ${ }^{, 72}$ Crucially for the present enquiry, Walter Moyle, who at the turn of the eighteenth-century wrote an essay on the Roman constitution, agreed with Sidney. ${ }^{73}$ From Moyle onwards, the argument in support of discord came to occupy a central place in texts that are usually seen as belonging to the commonwealth tradition. In his political discourses attached to a translation of Tacitus' works, Thomas Gordon closely paraphrased Moyle when

\footnotetext{
${ }^{64}$ Ibid, 31.10 .

${ }^{65} \mathrm{Ibid}, 32.9-12$. Shakespeare would later employ this bodily metaphor in the first scene of Coriolanus.

${ }^{66}$ Niccolò Machiavelli, The Discourses (c. 1515-19) (London: Penguin, 2003), 113-24. Among his contemporaries, Guicciardini disagreed strongly; see Millar, The Roman Republic in Political Thought, 78.

${ }^{67}$ Machiavelli, Discourses, 113.

${ }^{68}$ Ibid, 114.

${ }^{69}$ Ibid, 111.

${ }^{70}$ Ibid, 115.

${ }^{71}$ Pocock, The Machiavellian Moment, part III. On the commonwealth tradition, see Caroline Robbins, The Eighteenth-Century Commonwealthman (1959), (Indianapolis, IN, 2004).

72 James Harrington, The Commonwealth of Oceana (1656), (Cambridge, 2001), 29, 155, 158; Algernon Sidney, Discourses concerning Government (c. 1698), (Indianapolis, IN, 1996), 159-61.

${ }^{73}$ Walter Moyle, An Essay upon the Constitution of the Roman Government (c. 1699, published in 1721), Two English republican Tracts (Cambridge, 1969), 242-3, 246-7.
} 
writing that 'a free State the worst constituted...is, with all its disorders, factions, and tumults, preferable to any absolute Monarchy, however calm. ${ }^{, 74}$

At least as often read in the eighteenth century as Machiavelli's Discorsi was Montesquieu's short history of Rome, which repeated the Florentine's praise of internal discord. ${ }^{75}$ Montesquieu described how a secret war had been going on within the walls of Rome when it conquered the universe. ${ }^{76}$ Paraphrasing Machiavelli, the Frenchman said that '[o]n n'entend parler dans les auteurs que des divisions qui perdirent Rome; mais on ne voit pas que ces divisions y étaient nécessaires, qu'elles y avaient toujours été, et qu'elles y devaient toujours être. ${ }^{77}$ Montesquieu stressed that these divisions had been necessary to the martial spirit of Rome. Moreover, he contended that 'pour règle générale, toute les fois qu'on verra tout le monde tranquille dans un État qui se donne le nom de république, on peut être assuré que la liberté n'y est pas. ${ }^{78}$ In this context, it is evident that Montesquieu was referring to political liberty in a more active, republican sense, as opposed to civil liberty in the sense of security. In the Spirit of the Laws (1748), Montesquieu would single our virtue as the animating principle of ancient republics, whereas modern monarchies relied on the principle of honour. ${ }^{79}$

It appears as if Montesquieu wanted to signal some kind of agreement with Machiavelli on this topic. It is important to note, however, that while these 'Machiavellian' passages may sound straightforward, they are found in a chapter entitled 'Deux causes de la perte de Rome'. For a while, this dissension could produce harmony (harmonie), 'comme des dissonances dans la musique concourent à l'accord total. ${ }^{, 80}$ In the longer run, however, the expansion of Rome changed the nature of the republic; 'bonnes lois qui ont fait qu'une petite république devient grande lui deviennent á charge lorsqu'elle s'est agrandie, parce qu'elles étaient telles que leur effet naturel était de faire un grand peuple, et non pas de le gouverner. ${ }^{81}$ In other words, Rome

${ }^{74}$ [Thomas Gordon], The Works of Tacitus. Containing the Annals. To which are prefixed Political Discourses upon that Author (2 vols., London, 1728-31), 1:60. (Moyle: 'And who is there that would not prefer a factious liberty before such a settled tyranny?', in An essay upon the Constitution of the Roman Government, 247.)

${ }^{75}$ For recent discussions of Montesquieu's Roman history, see Paul A. Rahe, 'Montesquieu's antiMachiavellian Machiavellianism', History of European Ideas, 37 (2011), 128-36.

${ }^{76}$ Montesquieu, Considérations sur les causes de la grandeur des Romains et de leur décadence (1734), (Paris, 2008), 118.

${ }^{77}$ Ibid, 129.

${ }^{78}$ Ibid.

${ }^{79}$ Montesquieu, The Spirit of the Laws, bk. 3.

${ }^{80}$ Montesquieu, Considérations, 129 . The musical imagery suggests a commentary on Cicero's De re publica (2.69a), preserved and transmitted to us (and Montesquieu) via Augustine's De civitate Dei contra paganos (2.21).

${ }^{81}$ Montesquieu, Considérations, 130. 
was made for expansion, not for maintaining peace and stability: '[Rome] perdit sa liberté, parce qu'elle acheva trop tôt son ouvrage. ${ }^{82}$ Ultimately, Rome for Montesquieu was an anachronistic model of government, whereas for Machiavelli she presented a blueprint for success. $^{83}$

Although Montesquieu's qualified agreement with Machiavelli is often highlighted, the Frenchman's account shares some of the complexity found in the writings of his compatriot Jacques-Bénigne Bossuet, the seventeenth-century apologist for royal absolutism. Bossuet had argued that Rome 'portait en son sein la cause de sa ruine, dans la jalousie perpétuelle du peuple contre le sénat, ou plutôt des plébéiens contre les patriciens. ${ }^{84}$ The extreme positions espoused by each side, and the embracing of particular interests, led directly to the rise of Caesar and the fall of the Republic, according to Bossuet. ${ }^{85}$ As we will see, the same Janus-faced portrayal of internal discord in Rome was repeated in Ferguson's history. In short, eighteenth-century supporters of civilised monarchy such as Montesquieu and Ferguson were rarely straightforward Machiavellians, even if their language sometimes gave that impression. ${ }^{86}$

\section{III: FERGUSON'S ROME}

Montesquieu's brief masterpiece was one of the few early-modern works mentioned by Ferguson in his discussion of sources in the preface to the 1805 edition of the Roman Republic, and he described it as 'collecting into general points, what every reader may be pleased to observe in detail', with the implication that he would provide the details. ${ }^{87}$ Machiavelli, only referred to once in a footnote in the entire work, is conspicuous by his absence. ${ }^{88}$ Be that as it may, the 'Machiavellian' argument in praise of discord is indeed present in the Roman Republic, when Ferguson describes Rome 'as exhibiting the spectacle of a nation, which continued from the earliest ages to proceed in its affairs abroad with a success that may be imputed in a great measure to its divisions at home. ${ }^{99}$ Internal divisions

\footnotetext{
${ }^{82}$ Ibid, 131.

${ }^{83}$ Paul A. Rahe, 'The Book that Never Was: Montesquieu's Considerations on the Romans in Historical Context', History of Political Thought, 26 (2005), 43-89.

${ }^{84}$ Bossuet, Discours sur l'histoire universelle (1681), (Paris, 1966), 413.

${ }^{85}$ Ibid, 415.

86 There is no doubt that Ferguson was a supporter for the British monarchy. In December 1782, he wrote to the reformer Christopher Wyvill that 'I sincerely believe that to preserve the rights of the people the Vigour of the Crown is not less necessary than their own.' Correspondence, 2:292.

${ }^{87}$ Ferguson, Roman Republic, 1:xxv.

${ }^{88}$ Ibid, 1:9.

${ }^{89}$ Ibid, 2:221-2.
} 
and convulsions had the unintended consequence of turning Rome into 'the most excellent nursery of statesmen and warriors. ${ }^{, 90}$ Accordingly, 'the State, instead of being restrained, were impelled into action by intestine divisions. ${ }^{, 91}$

Ferguson's seemingly positive evaluation of the discord of Rome - which was qualified and unenthusiastic compared with that of Machiavelli and Moyle - may have set him apart from his friend Hume, ${ }^{92}$ but it was fairly mainstream in British discourse on Rome. For example, in the preface to his translation of the sixth book of Polybius' Histories, Edward Spelman wrote that 'Parties... are not only the Effect, but the Support of Liberty.' ${ }^{93}$ It is more worthwhile noting that Ferguson's remarks in favour of discord are few and far between compared with all his comments about the danger and disorder that party division brought on. Moreover, Ferguson differed from Machiavelli and Moyle by purporting to be genuinely puzzled by the fact that internal discord did more good than harm (up to a point) in Rome. Since Rome represented such a special case, 'to be paralleled in the history of mankind', it did not have many positive lessons to teach Britain in terms of how to provide an outlet for internal conflict, according to Ferguson: 'Contrary to the fate of other nations...the [Roman] State was in vigour, while the conduct of individuals was in the highest degree irregular and wild. ${ }^{94}$ At the same time, Ferguson said that Rome 'exhibit[ed] a scene interesting and instructive beyond any other in the history of mankind. ${ }^{95}$ As we shall see, however, one of the main lessons Rome could teach Britain was a negative one, namely that popular factions must be kept within strict bounds.

What is most striking about Ferguson's account is that he consistently takes the side of the 'senatorial' or 'aristocratical' party in Rome, rather than praising civic discord as such. Ferguson can be seen as an exponent of what has been called the Whig interpretation of Roman history in this respect. ${ }^{96}$ The Roman Senate was not an aristocratic body in the British sense of hereditary peerage, but rather in the Aristotelian sense of comprising the alleged aristoi, i.e. the best, or even more in the Latin meaning of senex as 'Old Man'. It was thus an assembly of elders, who received their authority from being related to the fathers of the

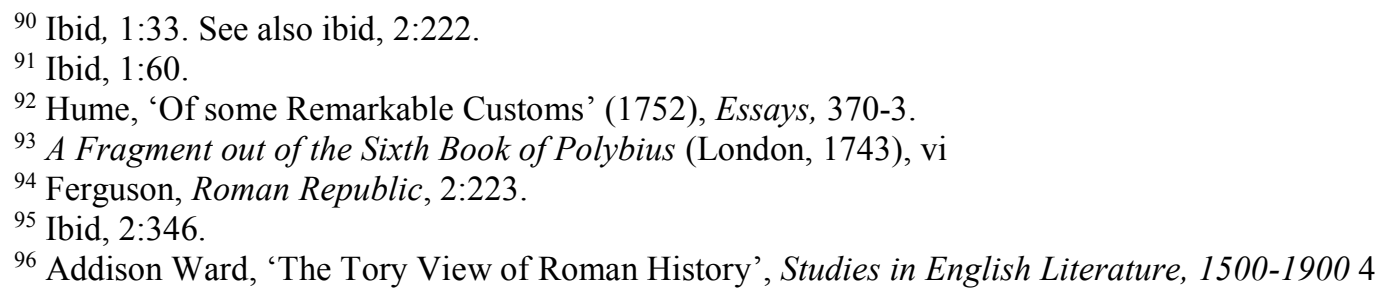


commonwealth. These were predominantly of patrician descent, but could also contain 'new men' like Cicero. ${ }^{97}$ In ancient terms, Ferguson was clearly an adherent of the 'optimate' notion of the institutional arrangements necessary to sustain liberty. ${ }^{98}$ This position was one favouring the mixed constitution but put special emphasis on the senate. It was particularly inspired by Cicero, but with its intellectual roots in Greeks such as Thucydides, Plato, and Polybius, whose writings had been formative for the Romans. A clear contrast of a mixed constitution theorist with a distinctly more popular bias would be Machiavelli. ${ }^{99}$ In short, the senate was for Ferguson's history what the populace were for Machiavelli (and Moyle), and the 'emperor' in Nathaniel Hooke's royalist account. ${ }^{100}$ Ferguson's history can helpfully be viewed as a response to Hooke, who was a known Jacobite; indeed, Ferguson borrowed Hooke's Roman history from his university library in $1777 .{ }^{101}$ To be clear, Ferguson did not approve of the 'entirely aristocratic' government that prevailed after the expulsion of the Tarquins, Rome's last kings. ${ }^{102}$ When the king and the senate shared power, one or the other would always side with the people. When the nobles were solely in command, however, the people were treated so badly that they refused to defend the state against external enemies. ${ }^{103}$ This led to the establishment of the tribunes, by which the peoples attained the right to elect their own representatives who could veto legislation.

For Ferguson, the establishment of the tribunes was not the triumphant event it had been for Machiavelli and Moyle; indeed, 'with it were laid the foundations of some good, and of much harm, to the commonwealth.' ${ }^{104}$ The reason was that, 'instead of a representation to support and preserve their own order with steadiness and moderation, they [the people] proceeded to elect a few leaders, who...were to head every popular tumult, and to raise every wind of contention into a storm. ${ }^{105}$ From the experience of the contest between the parties of the plebs and the patricians, Ferguson observed that 'fictitious plots and conspiracies were fabricated on the popular side, and fictitious designs against the liberties of the people were imputed to the Patricians, in order to render them odious, and to deter them from appearing in

\footnotetext{
${ }^{97}$ Millar, The Roman Republic in Political Thought, 170.

${ }_{98}$ Arena, Libertas and the Practice of Politics in the Late Roman Republic, 5-13, 60, 79-116, passim.

${ }^{99}$ Quentin Skinner, The Foundations of Modern Political Thought: Volume I: The Renaissance (Cambridge, 1978), 158-62.

${ }^{100}$ Nathaniel Hooke, The Roman History from the Building of Rome to the Ruin of the Commonwealth (4 vols., London, 1738-71).

101 J. B. Fagg, 'Ferguson's Use of the Edinburgh University Library: 1764-1806', Adam Ferguson:

History, Progress and Human Nature, 60.

${ }^{102}$ Ferguson, Roman Republic, 1:18.

${ }^{103}$ Ibid, 1:21-2.

${ }^{104}$ Ibid, $1: 25$.

${ }^{105}$ Ibid, 1:26.
} 
support of their real pretensions. ${ }^{, 106}$ Factional strife appears thus to have been beneficial only as long as the Romans were an austere and simple people. Ferguson's history followed Montesquieu in arguing that the 'the success of the [republic's] arms abroad, became the sources of a ruinous corruption at home', an argument with classical roots in Sallust and Polybius. ${ }^{107}$ When the wealth of the provinces began to flow into the city, a new type of factionalism arose: factions which competed about spoils rather than distinction. ${ }^{108}$

We should be careful not to let this line of reasoning lead us into characterising Ferguson as a detractor of commercialisation. ${ }^{109}$ Indeed, the basic narrative of luxury in Rome in was one he shared with Smith. ${ }^{110}$ Although Ferguson, like Smith, was critical of some of its side-effects, on balance he accepted and defended commercial society in modern Europe. ${ }^{111}$ A careful reading of Ferguson, moreover, reveals that he agreed with Montesquieu and Hume that the main problem was really, in the words of the latter, Rome's 'unlimited extent of conquests' and not luxury per se. ${ }^{112}$ In the Essay, Ferguson had reiterated Hume's distinction between luxury and corruption, even though he was more prepared than Hume to stress that excessive luxury could make people 'effeminate, mercenary, and sensual' in a vocabulary reminiscent of John Brown's best-selling Estimate of the Manners and Principles of the Times (2 vols., 1757-8). ${ }^{113}$ Such rhetoric was not only used by the likes of Ferguson and Brown, however, and the fact that thinkers recognised the distinction between luxury and corruption rarely meant that they denied the possibility that excessive bounty and booty could fuel corruption. For instance, in his efforts to impeach Warren Hastings for grave misconduct as Governor-general of Bengal, Burke said that 'wealth did what it generally does, it opened the door to corruption. ${ }^{, 14}$ The same Burke defended commercial society and free trade, notably in Thoughts and Details of Scarcity (1795). ${ }^{115}$ Realising the potentially corrupting

106 Ibid, 1:40-1.

${ }^{107}$ Ibid, 1:360; Pocock, Barbarism and Religion, 3:341-2.

${ }^{108}$ Ferguson, Roman Republic, 1:360.

${ }^{109}$ Such tendencies remain common, e.g. in Fania Oz-Salzberger, 'Scots, Germans, Republic, and Commerce', in Martin van Gelderen and Quentin Skinner (eds.), Republicanism: A Shared European Heritage. Volume II: The Values of Republicanism in Early-Modern Europe (Cambridge, 2002), 197-226, at 197-211.

${ }^{110}$ Istvan Hont, Politics in Commercial Society (Cambridge MA, 2015), 85-6.

${ }^{111}$ Berry, Hume, Smith and the Scottish Enlightenment, 119-21; Istvan Hont, 'Adam Ferguson on Commercial Nations', Intellectual History Archive, St Andrews, Intellectual-history: 161. See also note 174.

112 Hume, 'Of Refinement in the Arts' (1752), in Essays, 276 (Originally: 'Of Luxury'.) For Montesquieu, see Istvan Hont, 'The Early Enlightenment Debate on Commerce and Luxury' in The Cambridge History of Eighteenth-Century Political Thought, ed. Mark Goldie and Robert Wokler (Cambridge, 2006), 4078.

${ }^{113}$ Ferguson, Essay, 235-7.

114 Cited in Bourke, Empire and Revolutions, 631.

115 Richard Whatmore, 'Burke on Political Economy', in The Cambridge Companion to Edmund Burke, ed. David Dwan and Christopher J. Insole (Cambridge, 2012), 80-91. 
effects of luxury and wealth is not the same as either wanting, or believing it to be feasible, to roll back economic development.

Ferguson is commonly interpreted also as thinker stressing the importance of ambition. ${ }^{116}$ While this is certainly true to an extent, his Roman Republic leads us to qualify such conclusions. Here Ferguson explicitly singles out ambition as a mixed blessing with concomitant dangers. With ' $[\mathrm{t}]$ he Republic appear[ing] to be so feebly established...ambitious citizens were encouraged, by means of faction in the lower class of the people, to entertain hopes of subverting the government. ${ }^{117}$ This was how the conspiracy of Manlius arose. In the end, however, Manlius became accused of the very thing which Rome feared the most, that of aspiring to be king. ${ }^{118}$ The senate installed a temporary dictator who put down the conspiracy and the people condemned Manlius to be thrown from a rock in 384 BC. The execution of Manlius suspended 'party animosity' temporarily, but could not reconcile the interests of the plebeians and the patricians in the long run. ${ }^{119}$ Ferguson argued explicitly that the power of the senate and the consuls to nominate a dictator was an important instrument to keep the people in check. ${ }^{120}$ This is perfectly consistent with Ferguson's earlier political views, as when he said in the Institutes that domestic disorder renders discretionary power necessary on a temporary basis. ${ }^{121}$

Some two centuries after the people had been given a share in government, the distinction between patricians and plebeians was obliterated, Ferguson narrated, and gave way to a new distinction of 'nobles' and 'commons.' The nobles were a new type of aristocracy, one that Ferguson highly approved of: 'partly hereditary, founded in repeated succession of honours in the same family; and partly personal, founded in the habits of high station, and in the advantages of education and wealth, such as never fail to distinguish the conditions of men in every great and prosperous state. ${ }^{122}$ This new aristocracy was exemplified by the senate. These nobles, however, were not immune to the spirit of the times, and ' $[w]$ hen disappointed in the pursuit of riches abroad, they became the leaders of

${ }^{116}$ Lisa Hill, 'The invisible hand of Adam Ferguson', The European Legacy: Toward New Paradigms, 3 (6), 1998, 42-64, at 44.

${ }^{117}$ Ferguson, Roman Republic, 1:72.

${ }^{118}$ Ibid.

${ }^{119}$ Ibid, 74.

${ }^{120} \mathrm{Ibid}, 86$. For the dictatorship as an ancient, republican institution, see Straumann, Crisis and Constitutionalism, 64-74.

${ }^{121}$ Ferguson, Institutes, 303.

${ }^{122}$ Ferguson, Roman Republic, 1:361. 
dangerous factions at home.' ${ }^{123}$ As we shall see, Ferguson believed that the most dangerous nobles were the ones who, like Julius Caesar, betrayed their order and championed the cause of the people, or at least pretended to do so in order to find support for their personal ambitions.

Unsurprisingly, Ferguson gave the commons most of the blame for increased factionalism. Rome was after all the kind of state 'tending to popular license, and where justice is more likely to suffer from the unawed passions of the lower people.' ${ }^{124}$ With the state expanding, the number of people was constantly increasing, and, Ferguson emphasized, 'the very order of citizen itself was continually debased by the frequent accession of emancipated slaves.' ${ }^{125}$ Crucially, what he called the 'dreg'

became a part of that faction, who, being meanly debased, are actuated by envy to their superiors, by mercenary views, or by abject fear; who are ever ready to espouse the cause of any leader against the restraints of public order; disposed to vilify the most respectable ranks of men; and by their own indifference on the subjects of justice or honour, are able to frustrate every principle, beside those of force and terror, that may be employed for the government of mankind. ${ }^{126}$

As we know from Ferguson's response to 'Wilkes and Liberty', Ferguson was reluctant for the 'dreg' to play any public role whatsoever. In Rome, he concluded that 'we must suppose them to have been very improper members in the participation of government., 127 Fortunately, '[w]hile the inferior people of Rome sunk in their characters...the superior ranks...began to rise. ${ }^{128}$

This scenario was the prequel to what Ferguson regarded as the first serious attempt by a popular demagogue to undermine the Roman constitution, namely that of Tiberius Gracchus, with whom the final part of the first volume of the Roman Republic is concerned. Tiberius Gracchus was a tribune who, with 'all the accomplishments required in a popular leader, great ardour, resolution, and eloquence, formed a project in itself extremely alarming, and in its consequences dangerous to the very being of the State', that is to say, an agrarian

\footnotetext{
${ }^{123}$ Ibid, 1:363.

${ }^{124}$ Ibid, $1: 353$.

125 Ibid, 1:364.

126 Ibid.

${ }^{127}$ Ibid, 1:365-6.

${ }^{128}$ Ibid, 1:367.
} 
reform to mitigate inequality. ${ }^{129}$ Thomas Gordon had claimed that the agrarian reforms had indeed been necessary, although the way they were implemented equalled tyranny. ${ }^{130}$ By contrast, in all his writings, Ferguson consistently argued that redistribution of property to reduce inequality was both unjust and unwise. He also contended that it could have potentially fatal consequences for the Roman Republic, as he was convinced that ' $[t]$ he distinctions of poor and rich, in states of any considerable extent, are as necessary as labour and good government itself.' ${ }^{131}$ The division between economic and political actors in extensive states was necessary, according to Ferguson: '[ $t$ ]he poor being destined to labour, the rich, by the advantage of education, independence, and leisure, are qualified for public affairs. ${ }^{132}$ While the nobles were not free of selfish motives, Ferguson highlighted that the Gracchi episode demonstrated that they did not merely pursue their self-interest but also understood how essential the division between economic and political actors was to the survival of the state. The senatorial party thus strenuously opposed Tiberius Gracchus' scheme for essential and just reasons, mixed with private interest, while the opposite party supported the scheme solely 'from motives of envy, interest, or mistaken zeal for justice.' 133

In opposing agrarian reform, Ferguson was as ever in the optimates camp. However, his line of argument was far from a regurgitation of Cicero and others who opposed the later proposals of Julius Caesar. As Arena has shown, the optimates and popularis shared a basic conception of liberty as something which had to be protected from the domination of one group or individual from within or without the republic. In this environment, optimates such as Cicero rarely took issue with the principle behind agrarian reform, but instead concentrated their efforts on showing how the implementation of land distribution would give extraordinary powers to the commissioners in charge of its enactment. ${ }^{134}$ Ferguson's more explicit preoccupation with 'ranks' and their importance for political life and stability was very much an eighteenth-century fixation and a typical Scottish Enlightenment theme. ${ }^{135}$

${ }^{129} \mathrm{Ibid}, 1: 368$. This is a clear example of an explicit moral digression in the Roman Republic, and that it would be a mistake to think that they are exclusively 'implicit' as has been suggested in Vincenzo Merolle, 'Introductory Essay', The Manuscripts of Adam Ferguson, xxi, xxiv. On the Roman agrarian laws in ancient and early-modern political thought, see Eric Nelson, The Greek Tradition in Republican Thought (Cambridge, 2004), 49-86.

${ }^{130}$ [Thomas Gordon], The Works of Sallust Translated into English, with Political Discourses upon That Author (London, 1744), 79.

${ }^{131}$ Ferguson, Roman Republic, 1:370.

132 Ibid.

133 Ibid, 1:371.

${ }_{134}$ Arena, Libertas and the Practice of Politics in the Late Roman Republic, 241-2.

135 See, for instance, John Millar, The Origin of the Distinction of Ranks (1771). 
This is not to say that much of Ferguson's case was not indebted to the Roman optimates tradition. In the person of Tiberius Gracchus, he argued, the tribune became a means of 'hastening the effect of popular violence, instead of a drag-chain to the wheels of government, as was intended', and the state itself was faced with the 'prospect of anarchy, which threatened to end in some violent usurpation. ${ }^{136}$ In the end, Tiberius was slain together with three hundred members of his 'party' by the senatorial party. His proposed agrarian law was carried out, however, by his successors, among them his younger brother Caius Gracchus. Ferguson conceded that 'both the Senate and the People had been carried to acts of violence that insulted the laws and constitution of their country', but in the final analysis it was 'popular encroachments' that had reduced the government to a 'weak state.' 137

As soon as the aristocratic party had fully recovered the upper hand in public affairs, they declared Caius Gracchus and the other popular leaders who had succeeded Tiberius public enemies and killed them along with over three thousand of their party in the streets, while incarcerating and later murdering even more. Caius was cut up in pieces which were thrown in the river. ${ }^{138}$ However, unlike Oliver Goldsmith, who said that 'instead of calling the tumults of that time, the sedition of the Gracchi, we should rather call them the sedition of the senate against the Gracchi', ${ }^{139}$ Ferguson was not prepared to give any considerable blame to the aristocratic party, even though they had used a great deal of violence to subdue their opponents. Instead he argued that '[t]he popular party had, in the late tumults, carried their violence to such extremes, as disgusted and alarmed every person who had any desire of domestic peace; and, in their ill-advised recourse to arms, but too well justified the measures which had been taken against them. ${ }^{140}$ Moreover, the state seemed to return to normality after the violent suppression of the popular party.

Ferguson also applauded the senate for quelling with 'vigour and resolution' the later 'tribunitian sedition' of Marius and restoring the state to 'public order', referring to Sulla's military intervention. ${ }^{141}$ In stark contrast with Hooke, Ferguson portrayed Sulla in a somewhat favourable light as someone who was justified in taking arms and acting against 'tribunitian disorder' and credited him for resigning his dictatorship in a magnanimous

\footnotetext{
${ }^{136}$ Ferguson, Roman Republic, 1:381.

${ }^{137}$ Ibid, 1:389, 399.

${ }^{138}$ Ibid, 2:25-8.

${ }^{139}$ Oliver Goldsmith, The Roman History from the Foundation of the City of Rome to the Destruction of the Western Empire (2 vols., Dublin, 1769), 1:210.

${ }^{140}$ Ferguson, Roman Republic, 2:30.

${ }^{141}$ Ibid, 2:101.
} 
manner. ${ }^{142}$ The example of Sulla, as someone who made himself leader of the commonwealth by force, set a dangerous precedent, however, by 'exciting the thirst of dominion. ${ }^{143}$ After him, popular leaders would rise who 'proceeded, with a cool and deliberate purpose, to gratify their own ambition and avarice, by subverting the government of their country. ${ }^{144}$ These new 'adventurers' may have been 'indifferent to the interests of party as they were to those of the republic', but they were nevertheless willing to make use of popular discontent and faction for their own benefit. ${ }^{145}$ Ferguson's narrative has now entered the era of Catiline, Pompey and Caesar.

'Of all the cabals into which the popular faction was distributed, none was more desperate, nor supposed more dangerous, than that of Cataline [sic]', according to Ferguson. ${ }^{146}$ After failing to become consul, Catiline prepared an insurrection by appealing to the 'needy debtors' against the 'rich creditors' and plotting a massacre of the senate. ${ }^{147}$ The plans were famously exposed by Cicero, consul at the time, and the senate notoriously voted to execute without trial the conspirators who had been taken prisoners. Cato the Younger spoke in support of execution and Caesar against. ${ }^{148}$ According to Ferguson, the defeat of Catiline was achieved thanks to the handling of the 'great man' Cicero and the eloquence of the 'virtuous citizen' Cato. This account differed starkly from that of Sallust, who had portrayed Caesar in a rather positive light, stressing that what Caesar first and foremost argued against was the dangerous precedent of executing Roman citizens without trial. ${ }^{149} \mathrm{By}$ contrast, Ferguson emphasized that Caesar was only seeking to increase his own popularity and build himself a power base among the commons. ${ }^{150} \mathrm{He}$ further contended that the conspiracy of Catiline was allowed to progress as much as it did before it was shut down because 'there was not any regular method of resisting disorders, or of suppressing them on their first appearance.' ${ }^{151}$ In other words, Rome should have made better use of the constitutional and time-restricted dictatorship, which, according to Ferguson, could be used against charismatic leaders such as Catiline.

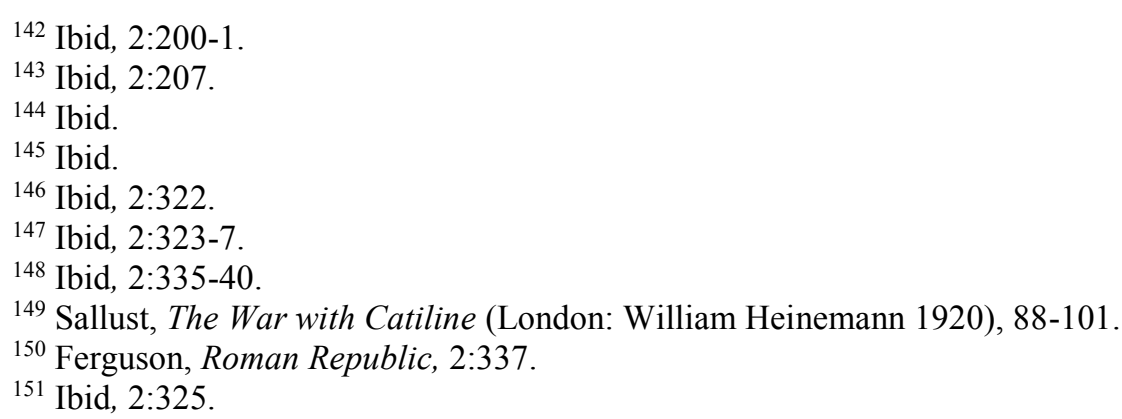


Ferguson's preference for and admiration of the senate is largely uninterrupted and in many ways the binding force of his narrative. ${ }^{152}$ This late era of the Roman Republic was one when 'in the capital all was confusion and anarchy, except where the Senate, by its authority and the wisdom of its councils, prevailed. ${ }^{, 153}$ By contrast, when 'the People...assumed the government into their own hands, or when the sovereignty was exercised in the name of the collective body, abuses were multiplied.' ${ }^{154}$ The populace were particularly vulnerable to fall prey to agitators. The result was that the provinces were oppressed at the pleasure of greedy individuals and 'the public interests and the order of the State were in perpetual struggle with the pretensions of demagogues, or of single and profligate men.' ${ }^{155}$

Ferguson observed that the "character of parties has already repeatedly changed, and the danger to be apprehended from them accordingly varied. ${ }^{156} \mathrm{He}$ divided the era of party conflict in the Roman Republic into three periods. Firstly, the commonwealth had been divided between patricians and plebeians, who were distinguished by birth and who 'strove for prerogative and privilege with much emulation, as separate orders of men in the commonwealth, but with little jealousy of personal interests. ${ }^{157}$ Later, when these distinctions had been removed, individuals started competing on a more equal footing, as leaders of the commons and the nobles, and formed 'separate factions' for these purposes. Accordingly, '[t]hey strove for the ascendant of aristocratical or democratical government, according to the interest they had formed to themselves in the prevalence of either. ${ }^{, 158}$ While ' $[\mathrm{t}]$ hey were ready to sacrifice the peace and honour of the Public to their own passions, and entered into disputes accordingly, which were in the highest degree dangerous to the commonwealth', they 'formed no deliberate plans of usurpation to enslave their country, nor formed a system of evils to continue beyond the outrage into which they themselves were led by their supposed personal wrongs or factious resentments. ${ }^{159}$ This is precisely what distinguished the third stage of factionalism, Caesar's phase, in Ferguson's view.

\footnotetext{
${ }^{152}$ In this particular instance, McDaniel's emphasis is slightly different, as he argues that 'Ferguson traced the decline of the political virtue of the Roman patricians throughout the entire text [my italics].' See McDaniel, Adam Ferguson, 149. I think the evidence weighs against this statement; see, for instance, note 128.

${ }^{153}$ Ferguson, Roman Republic, 2:345.

${ }^{154}$ Ibid, 2:345-6.

155 Ibid, 2:346.

156 Ibid, 3:79. (My emphasis.)

157 Ibid.

158 Ibid.

159 Ibid.
} 
Ferguson's Caesar had no principles but 'supported every party that was inclined to commit disorders in the State. ${ }^{160}$ He contrasted Caesar's Epicureanism with the public spirit of Cato, who embodied Roman Stoicism. ${ }^{161}$ Although there is no evidence of any conscious attempt to revise Epicureanism in eighteenth-century Scotland, this was a shorthand used by Ferguson (and others) to attack what he viewed as the 'selfish' philosophy and alleged atheism of Hobbes, Mandeville, and their perceived impact. ${ }^{162}$ Ferguson followed Montesquieu in arguing that the increasing dominance of Epicureanism, which could be seen as personified by Caesar, went a long way to explain the termination of the Roman Republic. ${ }^{163}$ Ferguson conceded that the senatorial party was fighting against the tide, and that the rise of monarchy was inevitable since the state had grown too extensive and too replete with luxury to maintain a republican government. ${ }^{164}$ Following Montesquieu, Ferguson was committed to the view that republicanism was only possible in small states, monarchy was preferable in medium-sized and larger states, and that too large states risked becoming despotic. ${ }^{165}$ The senate's virtue and constitutionalism were to be admired, but they were essentially rearranging the deck chairs on the Titanic. This does not mean, however, that Caesar was excused and that the senatorial party could have realized its folly, according to Ferguson, who emphasized the need to consider the matter in its own context: 'we must suppose ourselves in the situation of those who acted. ${ }^{, 166}$ From this perspective, the personal faction of Caesar, 'under pretence of zeal for higher measures of popular government than those they enjoyed, endeavoured to corrupt the people whom they meant to enslave', while the senatorial party simply 'contended for the rights, which, together with their fellowcitizens, they had inherited, as Romans.' 167

\footnotetext{
${ }^{160}$ Ibid, 3:237.

${ }^{161}$ Ibid, 2:347-57. For Ferguson's praise of Stoicism, see the introduction to volume two of his
} Principles or Moral and Political Science (1792). Notwithstanding this admiration, however, it is clear that Ferguson sought to develop his own independent philosophy. See Katherine Nicolai, 'Adam Ferguson's Pedagogy and his Engagement with Stoicism', Journal of Scottish Philosophy, 12 (2014), 199-212.

162 Epicureanism in the eighteenth century was primarily an accusation and indeed an insult, and there is not enough evidence to speak of 'The Epicurean Foundations of Enlightenments' in the Scottish context, as in Robertson, The Case for the Enlightenment, 316-24, building on James Moore, 'Hume and Hutcheson', in M. A. Stewart and John P. Wright (eds.), Hume and Hume's Connexions (Edinburgh, 1994). The question is rather if there is any historical evidence at all with relevance to Scotland besides attacks on straw men and philosophical similarity of the weaker kind. Here I agree with James Harris, 'Introduction: The Place of the Ancients in Moral Philosophy', Journal of Scottish Philosophy, 8 (2010), 1-11, at 4-6, which succinctly shows why it makes no sense in relation to Hume.

${ }^{163}$ Sher, Church and University in the Scottish Enlightenment, 199-202.

${ }^{164}$ Ferguson, Roman Republic, 5:70-1.

${ }^{165}$ Montesquieu, The Spirit of the Laws, 124-6; Ferguson, Essay, 69-70, 120, 126.

${ }^{166}$ Ferguson, Roman Republic, 5:71.

${ }^{167}$ Ibid, 5:71-2. 
The republic perished because of a new type of popular leader, aided by a new type of private faction: 'Caesar fomented the rage of political faction, to break down the barriers of public order, or make way for military force. ${ }^{168}$ This represents a major difference between Ferguson's account and that of Hooke, for whom Caesar was the great 'monarchical' hero rather than the villainous demagogue. ${ }^{169}$ Like Montesquieu, Ferguson followed the Machiavellian trajectory that internal conflict channelled into glory and conquest, which in turn led to the fall of the Roman Republic after over-expansion and the onset of corruption. What distinguished Ferguson and Montesquieu from Machiavelli was that the former two used it as a deterring example rather than as a model of government to be adopted, with the important caveat that Ferguson was eager for the British to embrace elements of the Roman military system. ${ }^{170}$ The reasons Ferguson, himself with a military background, had for doing so were not entirely different from Adam Smith's, with whom he shared an interest in both the potential benefits and dangers of the division of labour. ${ }^{171}$ Although they had been absent from Scotland in 1745, both Adams, who were born in the same year, had been shaped by the event of the Jacobite rebellion of 1745-6, when Charles Edward Stuart and his Highland armies occupied Edinburgh with minimal resistance, and marched as far south as Derby before they were pushed back and defeated at Culloden by Cumberland's professional forces. In the words of Smith in his Lectures on Jurisprudence, 'A commercial country may be formidable abroad, and may defend itself by fleets and standing armies, but when they are overcome and the enemy penetrates into the country, the conquest is easy. ${ }^{172}$ Ferguson was, however, a much more consistent defender of the militia than Smith, and one of the most prominent campaigners on the question in Scotland. ${ }^{173}$ Smith's praise of standing armies in the Wealth of Nations (1776) was the only flaw of that performance, according to Ferguson. 'You have provoked, it is true, the church, the universities, and the merchants, against all of

168 Ibid, 5:75.

${ }^{169}$ Hooke, The Roman History from the Building of Rome to the Ruin of the Commonwealth, 4:249.

${ }^{170}$ Vickie B. Sullivan, 'Against the Despotism of a Republic: Montesquieu's Correction of Machiavelli in the Name of the Security of the Individual', History of Political Thought 27 (2006), 263-89. Ferguson disagreed with Montesquieu about the separation between civil and military functions, and in that specific regard, the Romans could be a model to be adopted, according to the Scotsman. See note 13.

${ }^{171}$ On this, see Lisa Hill, 'Adam Smith, Adam Ferguson and Karl Marx on the Division of Labour', Journal of Classical Sociology, 7 (2007), 339-66; Richard Sher, 'Adam Ferguson, Adam Smith, and the Problem of National Defence', The Journal of Modern History, 61 (1989); Ronald Hamowy, 'Adam Smith, Adam Ferguson, and the Division of Labour', Economica, 35 (1968), 249-59.

${ }_{172}$ Smith, Lectures on Jurisprudence (Oxford, 1978), 541 (1766).

${ }^{173}$ Ferguson, Reflections; John Robertson, The Scottish Enlightenment and the Militia Issue (Edinburgh, 1985), esp. ch. 3 and 4. 
whom I am willing to take your part; but you have likewise provoked the militia, and there I must be against you', he wrote to Smith. ${ }^{174}$

Machiavelli recommended the republic of Rome because it was destined for expansion and the maximisation of glory, although he recognized that it had been more shortlived than republics made for preservation such as Sparta and Venice. ${ }^{175}$ By contrast, Montesquieu's goal in his Considerations was to contrast the martial world of the Romans with the commercial era of the eighteenth century in order to discourage his fellow Frenchmen from seeking dominion in Europe. ${ }^{176}$ Without being a through-and-through 'modern' like Hume, ${ }^{177}$ Ferguson agreed with Montesquieu that warlike republicanism was anachronistic in the eighteenth century - the era of the commercial, polite and civilized monarchy. ${ }^{178}$ 'Our Manners are so different, and the system upon which we regulate our apprehensions, in many things, so opposite, that no less could make us endure the practice of the ancient nations', Ferguson had written in the Essay. ${ }^{179}$ In typical Scottish Enlightenment spirit, he identified chivalry as the main dividing line separating the ancients and the moderns, an argument later adopted by Burke. ${ }^{180}$ The factional strife of Rome, even if it may have had beneficial side-effects in the early part of that curious and unparalleled historical case, could never be imitated in Britain of his own day. Instead, factional struggle, especially of the kind that involved popular discontent, was to be regretted and avoided.

${ }^{174}$ Ferguson to Smith, 18 April 1776, Correspondence, 1:143. In the same letter he wrote to Smith that 'I have been for time so busy reading you, and recommending and quoting you, to my students, that I have not had leisure to trouble you with letters...Y You are surely to reign alone on these subjects, to form the opinions, and I hope to govern at least the coming generations.' (1:142).

${ }^{175}$ Machiavelli, Discourses, 117. See also Pocock, Barbarism and Religion, 3:231.

${ }^{176}$ Istvan Hont, Jealousy of Trade: International Competition and the Nation-State in Historical Perspective (Cambridge and London, 2005), 28-9; McDaniel, Adam Ferguson in the Scottish Enlightenment, 15.

177 James Harris, Hume: An Intellectual Biography (Cambridge, 2015), 186-95, 284-5.

${ }^{178}$ Ferguson, Essay, 148, 235. For a recent discussion of the 'modern monarchy' of the eighteenth century, see Hont, Politics in Commercial Society, 77-8. Note that there were plenty of eighteenth-century references to Rome as a 'commercial republic', including in Voltaire and Smith; see Christopher Brooke, 'Eighteenth-century Carthage', in Commerce and Peace in the Enlightenment, ed. Béla Kapossy, Isaac Nakhimovsky and Richard Whatmore (Cambridge, 2017), 110-24. Note also that there was a Scottish eighteenth-century tradition, taking its cue from Andrew Fletcher, which, like Kant, regarded republicanism as peaceful, but Ferguson, who was on close terms with Fletcher's nephew Lord Milton, did not belong to this tradition; see Iain McDaniel, 'Peace, Commerce and Cosmopolitan Republicanism: The Legacy of Andrew Fletcher in Late-Eighteenth Century Scotland', in Commerce and Peace in the Enlightenment, 192-215.

${ }^{179}$ Ferguson, Essay, 185.

${ }^{180}$ Ibid, 191-3; John Millar, The Origin of the Distinction of Ranks (1771), (Indianapolis, 2006), 142; Burke, Reflections on the Revolution in France (1790), (London, 2004), 169-170. On this, see also Bourke, Empire and Revolutions, 700-708; Donald Winch, Riches and Poverty: An Intellectual History of Political Economy in Britain, 1750-1834 (Cambridge, 1996), 175-85. 


\section{IV: FERGUSON ON REPRESENTATION}

Ferguson's negative treatment of 'the popular cause' at Rome should not lead us into thinking that he was against the idea that different orders of the state should have a say in the legislative process. The distinctive quality of modern politics and especially the British constitution celebrated by Ferguson was the idea of representation. ${ }^{181}$ He agreed with Montesquieu that under the British constitution the people should preferably only be involved in government when electing their representatives. ${ }^{182}$ With the history of the Roman Republic, he sought to demonstrate to his contemporaries how dangerous it was for political leaders to appeal to sentiments 'out-of-doors' and to involve the populace directly in politics. Indeed, this is one reason why he had been so critical of the Rockingham Whigs and their association with the 'Wilkes and liberty' movement in $1768-70 .{ }^{183}$ He also shared Hume's negative opinion about Chatham (formerly William Pitt the elder), who he disparagingly referred to as a 'Demagogue.' ${ }^{184}$ While he was interested in encouraging what he referred to as the 'superior orders of the people' to participate more, principally in the military, he would fight tooth and nail to stop the intrusion of the populace into the running of the government. ${ }^{185} \mathrm{He}$ had already warned in the Remarks of 1776 that democratic politics in large states always led to military government and terminated political liberty for all. ${ }^{186}$

Even though he identified potential snags and threats, Ferguson's political ideal was Britain's mixed constitution rather than Rome, thanks to the modern notion of representation. It is true that the British constitution was often compared with the Roman model, but more incisive commentators such as Voltaire denied the relevance of the comparison. Voltaire believed that the harmony between the parts of the constitution made the British mixed government different (and superior) to that of Rome, which was so often engrossed by conflict between the orders of the state. ${ }^{187}$ The most important difference, however, was the idea of political representation, which many of Ferguson's contemporaries believed not to have been known to the Romans as a political concept. Hume had pointed out that the Roman people possessed the whole legislative power 'in a collective, not in a representative body. ${ }^{\text {' }} 88$

\footnotetext{
181 [Ferguson], Remarks, 13.

${ }^{182}$ Montesquieu, The Spirit of the Laws, 160.

183 Skjönsberg 'Adam Ferguson on Partisanship, Party Conflict, and Popular Participation', 17-26.

${ }^{184}$ Ferguson to Pulteney, 4 January 1770, Correspondence, 1:92.

${ }^{185}$ Ferguson to Pulteney, 7 Nov 1769, Correspondence, 1:82.

186 [Ferguson], Remarks, 23.

187 Voltaire, Letters Concerning the English Nation (London, 1733), 51-4.

${ }^{188}$ Hume, 'Politics a Science', Essays, 16.
} 
Rousseau put it most succinctly: 'The idea of Representatives is modern: it comes to us from feudal Government. ${ }^{189}$ Accordingly, one of the significant features of the Roman Republic, as Rousseau approvingly pointed out, was that all citizens (i.e. free-born males and freed slaves) had the right to vote without any property qualification through membership in the curiae, centuries or tribes, that is to say, the popular assemblies. ${ }^{190}$ Rome thus exemplified a system of genuine popular sovereignty ${ }^{191}$ rather than a representative system, according to Rousseau, who, unlike Emmanuel Joseph Sieyès, distinguished between the two.

In contrast with Rousseau, by stressing that the centuries 'were formed on a more artful idea, to make power accompany wealth', Ferguson argued that the Roman constitution 'implied a doubt whether the state should incline with the preponderance of numbers, or of property. ${ }^{192}$ He also argued that because the Roman citizens were spread over Italy, in practice 'They were represented... by partial meetings or occasional tumults in the capital; and to take the sense of the People on many a subject, was little better than to occasion a riot. ${ }^{, 193}$ Expanding on this discussion in his published lectures from 1792, Ferguson pointed out that the unfortunate distinction between free man and slave, and the plain fact that not every single citizens had participated either at Rome or Athens, meant that the ancient republics in practice had a 'casual' system of representation which had been both inadequate and unsafe, especially in Rome. ${ }^{194}$ By contrast, even though many were excluded from both public deliberations and the franchise, 'the liberty of the subject is more secure [in Britain] than perhaps it ever has been under any other human establishment.' ${ }^{195}$

The debate about representation and reform had been a key question in British political debate since the American crisis and the 'Wilkes and Liberty' of the 1760s and 70s (two catastrophes in Ferguson's view and questions where he strongly supported the government). Ferguson believed that all commoners were in principle represented in the House of Commons, even if only the propertied men had the vote. In his published university lectures, he opposed initiatives to extend the franchise. If someone were to construct the

189 Jean-Jacques Rousseau, The Social Contract and other later Political Writings (Cambridge, 1997), 114. Rousseau differed from both Montesquieu and Ferguson by being critical of representation, but only the idea that sovereignty, which had to be clearly distinguished from government, could be represented. On this, see Richard Tuck, The Sleeping Sovereign (Cambridge, 2016), ch. 3.

${ }^{190}$ Rousseau, The Social Contract, 132.

191 This argument was anticipated by Jean Bodin, who may well have been Rousseau's source; see Straumann, Crisis and Constitutionalism, 280-6.

192 Ferguson, Roman Republic, 1:7-8.

193 Ibid, 2:344-5.

${ }^{194}$ Ferguson, Principles, 2:472.

195 Ibid, 2:473. 
franchise from scratch, there would be a strong case to have as few exclusions as were 'consistent with reason and public safety.' ${ }^{196}$ As always, caution and stability were his primary concerns, however:

Where people indeed act by representation, their liberty depends more upon the character of the representative, than upon the form of proceeding, or the number of persons who are admitted to vote at elections; and when this matter is settled upon any sure footing that is safe, stability is of consequence more than any advantage to be gained by change. Too much fluctuation, or frequent transition from one set of rules to another, is, or all circumstances, the least consistent with the sense of security in which the possession and enjoyment of liberty consists. ${ }^{197}$

Montesquieu had defined liberty in the exactly the same terms in the Spirit of the Laws. ${ }^{198}$ In the final analysis, Ferguson believed that the British constitution represented an important advancement on the Roman Republic because it did not involve the populace directly in government. A relatable discussion was extant in Montesquieu's writings on the British constitution: as the representatives of the legislative body in Britain were more enlightened than the people, they could calm down stormy sentiments and commotion. ${ }^{199}$ When witnessing riots and how the Rockinghamite Whigs in particular appealed to popular opinion around 1770, Ferguson feared that Montesquieu had underestimated the threat that the populace posed to the British government. ${ }^{200}$

\section{V: CONCLUDING REMARKS}

Instead of a positive example, the fate of Rome thus had mainly a negative lesson to teach: that popular tumult had to be suppressed and private factions restrained. ${ }^{201}$ As we have seen, this could be done institutionally via representation rightly understood, which entailed that once representatives had been chosen they should be 'masters. ${ }^{202}$ In his vocabulary, Ferguson went further than the Rockingham Whig Burke, who, when arguing for the need for

${ }^{196}$ Ibid, 2:474.

197 Ibid, 2:474-5.

198 Montesquieu, The Spirit of the Laws, 157.

199 Ibid, 326.

${ }^{200}$ Ferguson to Pulteney, 7 Nov 1769, Correspondence, 1:83. Ferguson seems to have missed that Montesquieu had also been pessimistic about the future of Britain, but for different, 'Bolingbrokean' concerns about parliamentary corruption; see Montesquieu, The Spirit of the Laws, 166. For the BolingbrokeMontesquieu connection, see Rachel Hammersley, The English Republican Tradition and Eighteenth-century France (2010), (Manchester, 2016), 73-8.

201 The major exception is the importance of uniting civil and military functions (see note 13).

${ }^{202}$ Ferguson to Pulteney, 1 Dec 1769, Correspondence, 1:86. 
representatives to exercise independent judgement, nevertheless described himself as a 'devoted servant.' ${ }^{203}$ In the midst of the Wilkes episode, Ferguson believed that opposition leaders such as Burke's chief the Marquis of Rockingham attempted to 'rise upon the shoulders of the Mob. ${ }^{204}$ In his view, the career of Caesar showed the disastrous outcome when a charismatic and ambitious leader appeals exclusively to the self-interest of the populace. Ferguson consistently backed the senatorial party in its struggle against the popularis in Rome. The danger posed by the spirit of democracy when underpinned by political power was evident in the example of the Gracchi and their attempt to equalize conditions, which Ferguson unequivocally condemned. By contrast, he partially condoned Sulla, who, while establishing a dangerous precedent by taking power by force, only did so in order to curb the power of the popular party and the tribunes, and to restore the power of the senate and the optimates. According to Ferguson, Sulla was at least in part excused because he acted against disorder, popular license and tyranny, whereas he saw the Gracchi as acting from and appealing to sentiments of self-interest and envy as well as inciting popular violence. For these reasons, he celebrated the Roman dictatorship as a temporary constitutional mechanism, which could be utilized to prevent despotism rather than exemplifying it. In the Essay, he had compared the Roman dictatorship with the executive suspension of habeas corpus in Britain - a measure he had a track record of recommending. ${ }^{205}$

Conflict in the early history of Rome may have had beneficial side-effects, but this is of minor concern in Ferguson's account. Instead he focused on period of just over one hundred years which encompassed the violence of the Gracchi era, the civil war between Marius and Sulla, Catiline's conspiracy, the conflict between Caesar and Pompey, followed by the war between Octavian and Antony, and, finally, the rise and ascendency of Augustus. Caesar is introduced already in the second volume in the slightly revised five-volume set. The early Romans had played a major role in Ferguson's Essay, which was more concerned with human associations and what we would today call anthropology and sociology rather than narrative history. Availability of sources may have played a part in this decision. Thanks to

\footnotetext{
${ }^{203}$ Speech to the Electors of Bristol (1774), in Select Works of Edmund Burke (4 vols., Indianapolis, 1999), 4:12

${ }^{204}$ Ferguson to Pulteney, 7 Nov 1769, Correspondence, 1:83.

${ }^{205}$ Ferguson, Essay, 143. During the 'Gordon Riots' in 1780, he had written to his friend Macpherson that 'the consequence of systematic or repeated riots near the vitals of Government are such that I think the Habeas Corpus should be suspended as often as a Riot is continued or repeated after 24 hours' (Correspondence, 1:239).
} 
the speeches and letters of Cicero and the writings of Sallust, Rome of the first century BC is much better known than the preceding period, for Ferguson as well as for us. But it was more importantly a question of priorities and the story he wanted to tell, which was different than the one told by Machiavelli in his Discourses on Livy. Machiavelli, at least ostensibly, focused on the first ten of Livy's one hundred and forty books (most of which have been lost), in other words, the early history of Rome, ${ }^{206}$ whereas Ferguson decided to concentrate on the late republic and the transition to empire. On balance, Ferguson's history of Rome has to be read as a work critical of factional strife and popular discontent rather than an attempt at explaining their utility.

This interpretation of the History presents Ferguson as a more conventional Scottish eighteenth-century thinker than has often been claimed, notably by Pocock. Often portrayed as an advocate of civic discord and factionalism, this article has demonstrated that he is better read as a thinker concerned with ensuring stability and security under the rule of law. This outlook was typical of the Scottish Enlightenment attention to political stability. Some of Scotland's conflicts had receded after the Jacobite defeat at Culloden in 1746, and in particular William Pitt the Elder's recruitment of forces from the Highlands during the Seven Years' War. ${ }^{207}$ However, the memory and sheer immediacy of conflict, to a large degree as a legacy of the Reformation, prompted an anxiety about stability and a dread of internal strife. Ferguson's friend Smith believed that Scotland had benefited greatly from the abolition of its parliament in 1707 by eluding party politics. In the conclusion of the Wealth of Nations (1776), when discussing the possibility of a parliamentary union between the thirteen colonies of America and Britain, Smith argued that one of the benefits of such a union was that the colonies would escape the 'spirit of party', a spirit 'which commonly prevails less in the remote provinces than in the centre of the empire.' London would inevitably be the centre stage of factional disputes and party rage. 'The distance of those provinces from the capital, from the principal seat of the great scramble of faction and ambition', he continued, 'makes them enter less into the views of any of the contending parties, and renders them more indifferent and impartial spectators of them all.' Smith concluded with the comparison that 'The spirit of party prevails less in Scotland than in England', leaving no reader in doubt

\footnotetext{
${ }^{206}$ According to Ferguson, what had been preserved from Livy was 'but the meaner and less authentic part of his work' (Roman Republic, 1:xv).

${ }^{207}$ Anon, A Full and Free Inquiry into the Merits of the Peace; With some Strictures on the Spirit of Party (London, 1765), 143-4. However, Scotland was excluded from Pitt's 1757 Militia Act, which Ferguson (most likely) wrote against in an anonymous pamphlet called History of the Proceedings in the Case of Margaret, Commonly called Peg, only lawful Sister to John Bull, Esq. (London, 1760).
} 
whether this was a great advantage in his mind. ${ }^{208}$ We have little reason to suspect that Ferguson would have disagreed.

Like Smith and other luminous contemporaries such as Burke and Gibbon, Ferguson was confounded by the French Revolution. ${ }^{209}$ His letters in the 1790 s include allusions to 'democracy' and 'anarchy', and suggestions that these ideas have captured the French army and attained an agency of their own. ${ }^{210}$ The inevitable transition from democracy to despotism was the great leitmotif across Ferguson's oeuvre. ${ }^{211}$ Although making up for its initial failure was certainly also a key part of his motaivation, the fact that he republished the Roman Republic with minuscule changes in 1799 suggests that he thought that it was the optimal case study for understanding the forces threatening the political culture of Europe in his lifetime. ${ }^{212}$ The forces identified by Ferguson consisted of imperial expansion and standing armies, ${ }^{213}$ but also the related questions of demagogues and self-seeking factions misleading a corrupted populace to undermine constitutional balances. In his quest for preeminence, Caesar had abandoned his own noble class and laboured to turn the people from an order intent on protecting its rights into a power-hungry faction. In the process, the mixed constitution had effectively been terminated and the foundations of despotism erected. Ferguson had provided hints of this analysis in the Essay, ${ }^{214}$ and his history of the Roman Republic was to a great extent an elaboration of this theme. This was a style of political thinking in the mould of traditional mixed constitutionalism with its roots in Aristotle and Polybius, which in the eighteenth century had been sharpened by Montesquieu's theory of intermediary powers. ${ }^{215}$ When William Robertson stressed the importance of intermediary

${ }^{208}$ Adam Smith, An Inquiry into the Nature and Causes of the Wealth of Nations (1776), (2 vols., Oxford, 1976), 2:945.

${ }^{209}$ However, unlike Smith, Burke and Gibbon, who all died in the 1790s, the last two in the belief that the world they knew had been destroyed, Ferguson lived on until 1816, which is perhaps why his one sustained examination of the question, from 1806, dealt mainly with geo-politics from a British perspective. See Ferguson, 'Of the French Revolution with its Actual and Still Impending Consequences in Europe' (1807), The Manuscripts of Adam Ferguson, 133-141. For a fuller account of Ferguson's response to the French Revolution, see Anna Plassart, The Scottish Enlightenment and the French Revolution (Cambridge, 2015), 125-55.

${ }^{210}$ Ferguson to Carlyle, 2 October, 1797, in Correspondence, 2:422-3.

${ }^{211}$ Ferguson, Essay, 73.

212 Ferguson compared Caesar and Bonaparte in a letter to John Macpherson, 1 August 1798, Correspondence, 1:442.

${ }^{213}$ As identified in McDaniel, Adam Ferguson in the Scottish Enlightenment, esp. ch. 5.

${ }^{214}$ Ferguson, Essay, 130, 178-9.

215 Ibid 124, 127, 258-9. For Montesquieu, see Céline Spector, Montesquieu: liberté, droit et histoire (Paris, 2010), esp. 92-105, 257-70. 
powers, and in particular the nobility as a bulwark against absolute monarchy, in his 'View of the Progress of Society in Europe' (1769), he cited Ferguson alongside Montesquieu. ${ }^{216}$

In order to sustain constitutional balances, civic virtue - a selfless devotion to the public good and the preservation of the community - was a prerequisite in Ferguson's mind. ${ }^{217}$ Pace Straumann, Machiavelli had also viewed constitutional orders and virtue as connected: people are naturally fickle and selfish, and need to be compelled into action by constitutional mechanisms, which will make it in their interest to work for the common good. ${ }^{218}$ Nevertheless, a key difference was that Machiavelli, like the ancients, interpreted history as cyclical, whereas Ferguson, like most Scottish Enlightenment thinkers, but unlike many other eighteenth-century writers including Bolingbroke, viewed history as progressive. ${ }^{219}$ Importantly, however, this did not imply that progress was inevitable and that states could not fail. His point was that human institutions did not have natural lifespans; in other words, that 'no nation ever suffered internal decay but from the vice of its members. ${ }^{220}$

Much intellectual history has been organised around simple dichotomies such as religion versus Enlightenment, tradition versus modernity, landed property versus commerce, Epicureanism versus Stoicism, republicanism versus liberalism, and, recently in Straumann's book, civic virtue versus constitutionalism. Although we have certainly moved away from some of these historically misleading contrasts, this binary way of thinking about past debates is a persistent feature in scholarship. Such dichotomies can be helpful for pedagogical purposes, but even though generalisations usually contain a grain of truth they always lack nuance. We need to remember that intellectual actors do not really have to make such straight choices, although political actors and party members often do. Just as Hume could be neither a Whig nor a Tory, Ferguson was a progressive, indeed teleological, thinker deeply concerned with the possibility of decline.

\section{Acknowledgements:}

${ }^{216}$ Robertson, The History of the Reign of the Emperor Charles V (4 vols., 10 ed., London, 1802), $1: 203$.

${ }^{217}$ Ferguson, Essay, 251.

${ }^{218}$ Machiavelli, The Discourses, 111-124.

${ }^{219}$ On this, see Silvia Sebastiani, The Scottish Enlightenment: Race, Gender, and the Limits of Progress (New York, 2013). John Adams, drawing on both Bolingbroke and Ferguson, combined insights from both interpretations.

${ }^{220}$ Ferguson, Essay, 264. 
I presented earlier drafts of this article at the annual conference of the International Society for Intellectual History (ISIH) at St Andrews, a workshop on new research in the history of political thought at the University of York, both in June 2018, as well as the EighteenthCentury \& Enlightenment Studies Seminar at the University of Edinburgh in November 2018. Many thanks are particularly due to Tim Stuart-Buttle, who commented on my paper at the event in York. I have also benefited from conversations with and comments from Thomas Ahnert, Janet Chan, Robin Douglass, Signy Gutnick-Allen, Adela Halo, Tim Hochstrasser, Robin Mills, Johan Olsthoorn, and Ian Stewart. Finally, I would like to thank the journal's two anonymous reviewers. 